Potravinarstvo Slovak Journal of Food Sciences

vol. 14, 2020, p. 1105-1114

https://doi.org/10.5219/1405

Received: 26 May 2020. Accepted: 16 November 2020.

Available online: 28 November 2020 at www.potravinarstvo.com

(C) 2020 Potravinarstvo Slovak Journal of Food Sciences, License: CC BY 3.0

ISSN 1337-0960 (online)

\title{
MONITORING OF MICROSCOPIC FUNGI COMMUNITY IN SELECTED BEE PRODUCTS
}

\author{
Zuzana Mašková, Vladimíra Kňazovická, Veronika Mančíková, \\ Dana Tančinová, Zuzana Barboráková
}

\begin{abstract}
Honey is a remarkably complex food with a valued place in the human diet. An important indicator of its quality is the presence of microorganisms. This study aimed to monitor the mycological quality of 27 samples of Slovak kinds of honey and honey products with the addition of differently processed blueberries, cranberries, and red currants. Yeast and filamentous microscopic fungi were monitored using the plate dilution method. A total of 21 samples (78\%) were positive for the presence of yeasts and 14 samples (52\%) were positive for the filamentous microscopic fungi occurrence. In 6 samples (22\%) no presence of microscopic fungi was found at all. The highest number of yeasts (3.07 log CFU. $\mathrm{g}^{-1}$ ) was recorded in one flower honey sample and in other samples, yeast counts did not exceed $3 \log \mathrm{CFU} . \mathrm{g}^{-1}$. The highest numbers of filamentous micromycetes (2.39 and $2.44 \log \mathrm{CFU} . \mathrm{g}^{-1}$ ) were recorded in 2 honeydew honey samples. Overall, the following genera have been identified: Alternaria, Arthrinium, Aspergillus (including previously named as Eurotium), Aureobasidium, Cladosporium, Mucor, Penicillium, and Stemphilium. Penicillium spp. were recorded with the highest isolation frequency (41\%). Aspergillus species were isolated from $19 \%$ of honey samples. In the honey with fruit addition, the yeasts in a range of $1.00-3.09 \log$ CFU. $\mathrm{g}^{-1}$ and the filamentous microscopic fungi in a range of $1.00-1.39 \log$ CFU. $\mathrm{g}^{-1}$ were found. The study showed that cranberries were the most appropriate addition from a mycological point of view. Dried and lyophilized forms of tested fruits were the most suitable. Except for honey with frozen currants and honey with fresh cranberries, all final products had a water activity below 0.610 and appeared to be stable.
\end{abstract}

Keywords: blueberry; cranberry; honey; micromycetes; red currant.

\section{INTRODUCTION}

Honey is a remarkably complex food that, contains more than 200 biologically active compounds. The main components of honey are carbohydrates and water. Some minor components present in honey are minerals, phenolic acids and flavonoids, ascorbic acid, proteins, certain enzymes, amino acids, organic acids, $\alpha$-tocopherol, carotenoids, and Maillard reaction products (Korošec et al., 2016).

Honey is characterized by medicinal effects and antimicrobial properties and is used in various cuisines. The application potential in bakery, confectionery, snack foods, fruit, and vegetable products and beverages is everincreasing (Aparna et Rajalakshmi, 1999). Nowadays there is an ever-increasing demand for consumer-based diversified honey products, which lead to value addition to the raw material. The honey-based spreads increase the demand for honey and provide superior products to the customers in terms of nutrition and taste (Umesh Hebbar,
Rastogi and Subramanian, 2008). Honey can be enriched with various additives such as nuts, well-dried herbs, spices, or fruits (Dadant, 2019). According to Krell (1996) for the production of honey with added fruit, it is best to use soft, sun-dried fruits with the lowest possible water content. Fresh fruit can become contaminated and mildewed (Dadant, 2019).

As a therapeutic product, honey has been used since ancient times. Its medical use represents support for the treatment of cold and flu, insomnia, liver and gallbladder diseases, or heartburn. Because honey contains digestive enzymes, it helps reduce excess fat in the human body (Chaven, 2014). Its properties are chemically evidenced by its composition. Among features that make this product effective against microorganisms, we can quote high osmotic pressure by low water activity (average 17.2\%); low $\mathrm{pH}$ because of the presence of organic acids (average 3.9); the presence of hydrogen peroxide generated by the action of enzyme glucose oxidase; low protein content; low 
redox potential due to the presence of reducing sugars; and chemical agents present as lysozyme, phenolic acids, pinocembrin, terpenes, benzyl alcohol, and volatile substances (Rao et al., 2016; Snowdon and Cliver, 1996). Despite all the honey microorganism barriers, some species of microorganisms can survive and may cause damage to honeybees or consumers (Silva et al., 2017). Primary sources of microbial contamination are likely to include pollen, the digestive tracts of honey bees, the environment inside the beehive, dust, air, flowers, nectar, sources that are very difficult to control. Secondary (after-harvest) sources of contamination include air, food handlers, crosscontamination, equipment, and buildings, and these can be controlled by good manufacturing practices (Snowdon and Cliver, 1996; Olaitan, Adeleke and Ola, 2007). Microbes of concern in post-harvest handling are those that are commonly found in honey (i.e., yeasts and spore-forming bacteria), those that indicate the sanitary or commercial quality of honey (i.e., coliforms and yeasts), and those that under certain conditions could cause human or honeybee illness (Snowdon and Cliver, 1996).

Fungi can colonize most of the substrata on Earth. Honey is a reservoir of xerotolerant and xerophilic fungi and should be an ideal substratum for their development. Flowers and aphids could play an important role as a source of such microorganisms. However, little information has been gathered about these fungi and their relationships with honey and honey products. Honey has been studied little in terms of its fungal diversity (Rodríguez-Andrade et al., 2019). Filamentous fungi and yeasts can maintain their vegetative form (Snowdon and Cliver, 1996). They can remain latently in this product waiting for the moment in which the environment is suitable for their development (Silva et al., 2017). They may participate in the fermentation and decay of honey. Yeast activity can cause foaming of the honey surface, smell, and taste of the fermented product (Př́́dal, 2005). Soni et al. (2016) state, that the detection of yeast counts in honey is a complementary factor in determining the quality of honey. Growth of some filamentous fungi could be followed by the production of mycotoxins, which are secondary metabolites of filamentous fungi and toxic to humans and animals even in small concentrations (Pitt, 2000). Among mycotoxin producers, we should highlight Aspergillus spp. and Penicillium spp. because they are the most commonly found in honey (Foley et al., 2014; Sinacori et al., 2014). They are also associated with diseases in honeybees (Silva et al., 2017).

It is important to know the diversity of contaminating microorganisms in honey, especially due to disseminate pathogenic microorganisms in international traded marketing (Silva et al., 2017). In general, honey should be considered as a "living food" and, consequently, its "normal" mycobiota merits more extensive study (Rodríguez-Andrade et al., 2019).

The aim of the present study was therefore to monitor the mycological quality of Slovak honey and selected honey products with added fruit. The fruit affects the basic Physico-chemical properties of the honey, and it may impact their stability and the development of micromycetes, so we aimed to estimate the safety of these products in terms of the yeast and filamentous microscopic fungi occurrence.

\section{Scientific hypothesis}

Honey contains various microorganisms, including microscopic fungi, which may, under certain circumstances, affect its quality and safety.

\section{MATERIAL AND METHODOLOGY}

Analyses in the present study were divided into two parts. The first were analyses of honey samples recovered from the Slovak production and the second were analyses of honey with the addition of various fruits. All analyses were focused on the detection of microscopic fungi in the monitored commodities, namely yeasts and filamentous microscopic fungi.

\section{Honey}

A total of 27 different honey samples were mycologically monitored (20 samples from the year 2018 and 7 samples from the year 2019). A list of honey samples with their characteristics is given in Table 1. All samples were obtained directly from beekeepers.

Each honey sample in the present study was tested for the occurrence of yeasts and filamentous microscopic fungi using a plate dilution method and appropriate culture media.

\section{Honey with the addition of fruit}

In the second part of the study, were (under laboratory conditions) prepared samples of honey with the addition of various fruits in various forms and concentrations. The fruits used in this study were blueberries (frozen, dried, and lyophilized), cranberries (fresh, dried, and lyophilized), and red currants (frozen, dried, and lyophilized). Table 2 provides a more detailed description of the raw materials used to prepare the products. Weighed fruits were mixed with rapeseed pasted honey, particularly in the concentrations shown in Table 3, and have been thoroughly homogenized. Concentrations were designed according to the expected water content of the used fruit. With decreasing water concentration in fruits, the content of their addition was increased. The products were stored in glass containers in a cool and dark place. Mycological analyses were performed both on individual raw materials and final products, all variants in 3 repetitions.

\section{Mycological analyses}

Mycological analyses of honey samples, fruit samples, and honey samples with additives were aimed at determining the total counts of yeasts and filamentous microscopic fungi. A plate dilution method was used for the above analyses. The procedures were followed according to Slovak technical standards - STN ISO 21527-1 (2010) and STN ISO 215272 (2010). Two nutrient media were used according to the water activity of the particular sample analyzed. For samples with water activity greater than 0.95 , DRBC nutrient medium (Dichloran Rose Bengal Chloramphenicol Agar; Himedia, M1881) was used. 
Table 1 Slovak origin honey samples monitored for the microscopic fungi occurrence.

\begin{tabular}{|c|c|c|c|}
\hline $\begin{array}{l}\text { Sample } \\
\text { number }\end{array}$ & Botanical origin & Geographical origin & $\begin{array}{c}\text { Year of } \\
\text { production }\end{array}$ \\
\hline 1 & blossom (sunflower) & Dunajská Lužná (Senec) & 2018 \\
\hline 2 & blossom (acacia) & Nitra (Nitra) & 2018 \\
\hline 3 & blossom (linden) & Nitra (Nitra) & 2018 \\
\hline 4 & blossom & Nitra (Nitra) & 2018 \\
\hline 5 & blossom (sunflower) & Nitra (Nitra) & 2018 \\
\hline 6 & honeydew & Nitra (Nitra) & 2018 \\
\hline 7 & blossom (buckwheat) & Rišňovce (Nitra) & 2018 \\
\hline 8 & buckwheat & Dežerice (Bánovce nad Bebravou) & 2018 \\
\hline 9 & blossom (acacia) & Dežerice (Bánovce nad Bebravou) & 2018 \\
\hline 10 & blossom & Malé Kršteňany (Partizánske) & 2018 \\
\hline 11 & blossom & Babín (Námestovo) & 2018 \\
\hline 12 & blossom & Horná Orava (Námestovo) & 2018 \\
\hline 13 & blossom & Dolný Pajer (Žarnovica) & 2018 \\
\hline 14 & blossom & Smrečany (Liptovský Mikuláš) & 2018 \\
\hline 15 & blossom & Smrečany (Liptovský Mikuláš) & 2018 \\
\hline 16 & blossom (spring) & Nová L'ubovňa (Stará Lubovňa) & 2018 \\
\hline 17 & honeydew & Nová L'ubovňa (Stará L'ubovňa) & 2018 \\
\hline 18 & blossom & Orlov (Stará L’ubovňa) & 2018 \\
\hline 19 & blossom & Orlov (Stará L'ubovňa) & 2018 \\
\hline 20 & honeydew & Orlov (Stará L'ubovňa) & 2018 \\
\hline 21 & blossom (linden) & Nitra (Nitra) & 2019 \\
\hline 22 & honeydew & Nitra (Nitra) & 2019 \\
\hline 23 & honeydew & Nitra (Nitra) & 2019 \\
\hline 24 & honeydew & Dolný Pajer (Žarnovica) & 2019 \\
\hline 25 & honeydew & Dolný Pajer (Žarnovica) & 2019 \\
\hline 26 & honeydew & Žarnovica (Žarnovica) & 2019 \\
\hline 27 & honeydew & Žarnovica (Žarnovica) & 2019 \\
\hline
\end{tabular}

Table 2 Characteristics of raw materials used for the production of honey with added fruit.

\begin{tabular}{|c|c|c|c|c|}
\hline $\begin{array}{l}\text { Sample } \\
\text { number }\end{array}$ & Raw materials & Country of origin & $\begin{array}{c}\text { Year of } \\
\text { production } \\
\text { /min. } \\
\text { durability* }\end{array}$ & Comments \\
\hline 1 & honey & $\begin{array}{l}\text { Slovakia } \\
\text { (Malé Kršteňany) }\end{array}$ & 2017 & $\begin{array}{l}\text { rapeseed, pasted, without heating, } \\
\text { purchased from a beekeeper }\end{array}$ \\
\hline 2 & blueberries - frozen & $\begin{array}{l}\text { Slovakia } \\
\text { (High Tatras) }\end{array}$ & 2018 & obtained by direct harvesting \\
\hline 3 & blueberries - dried & unknown & 2018 & $\begin{array}{l}\text { bought in the shopping centrum in } \\
\text { Nitra - for the weight }\end{array}$ \\
\hline 4 & $\begin{array}{l}\text { blueberries - } \\
\text { lyophilized }\end{array}$ & Chile & June $2020^{*}$ & ecological agriculture \\
\hline 5 & cranberries - fresh & USA & $2019^{*}$ & 1st class product \\
\hline 6 & cranberries - dried & USA & $2019 *$ & $\begin{array}{l}1 \text { st class product, purchased in an } \\
\text { organic shop }\end{array}$ \\
\hline 7 & $\begin{array}{l}\text { cranberries - } \\
\text { lyophilized }\end{array}$ & Germany & $2020 *$ & $\begin{array}{l}\text { whole lyophilized fruits purchased } \\
\text { through the e-shop }\end{array}$ \\
\hline 8 & red currants - frozen & Slovakia (Smrečany) & 2018 & obtained by direct harvesting \\
\hline 9 & red currants - dried & Poland & $2019 *$ & whole fruits \\
\hline 10 & $\begin{array}{l}\text { red currants - } \\
\text { lyophilized }\end{array}$ & Germany & 2017 & whole fruits \\
\hline
\end{tabular}


Table 3 Concentrations of individual fruits used for the preparation of honey with additives.

\begin{tabular}{ccccc}
\hline \multirow{2}{*}{$\begin{array}{c}\text { Product } \\
\text { number }\end{array}$} & Quantity [g] & Truit & Honey quantity & \multicolumn{2}{c}{$\begin{array}{c}\text { Fruit } \\
\text { [g] }\end{array}$} & $\begin{array}{c}\text { concentration } \\
{[\% \text { \%] }}\end{array}$ \\
\hline 11 & 2 & blueberries - frozen & 98 & $\mathbf{2}$ \\
12 & 10 & blueberries - dried & 90 & $\mathbf{1 0}$ \\
13 & 12 & blueberries - lyophilized & 88 & $\mathbf{1 2}$ \\
14 & 4 & cranberries - fresh & 96 & 4 \\
15 & 10 & cranberries - dried & 90 & 10 \\
16 & 6 & cranberries - lyophilized & 94 & 6 \\
17 & 6 & red currants - frozen & 94 & $\mathbf{6}$ \\
18 & 10 & red currants - dried & 90 & $\mathbf{1 0}$ \\
19 & 12 & red currants - lyophilized & 88 & $\mathbf{1 2}$ \\
\hline
\end{tabular}

In the case of samples with a water activity less than or equal to 0.95 , the DG18 medium (Dichloran 18\% Glycerol Agar; Himedia, M1129) was used. Cultivation was performed under aerobic conditions at $25{ }^{\circ} \mathrm{C}$ for $5-7$ days. Grown colonies were converted to colonies forming unit (CFU), using the formula (1)

$$
\mathrm{N}=\Sigma \mathrm{C} /[(1 \times \mathrm{n} 1)+(0.1 \times \mathrm{n} 2)] \mathrm{d}
$$

where $\mathrm{N}=$ number of colonies per milliliter or gram, $\Sigma \mathrm{C}=$ sum of all colonies on all plates counted, $\mathrm{n} 1=$ number of plates in lower dilution counted, $\mathrm{n} 2=$ number of plates in next highest dilution counted, $\mathrm{d}=$ dilution from which the first counts were obtained.

Filamentous microscopic fungi were subsequently identified into the genera. The identification was based on the observation of macro- and micromorphological features, using respected mycological keys (Samson et al., 2002; Pitt and Hocking, 2009; De Hoog, Guarro, and Gene, 2000).

\section{Water activity $\left(a_{w}\right)$ determination}

The reference device, LabMaster-aw from Novasina, was used to determine the water activity of the raw materials and honey products. The measurements were performed at a constant temperature of $25{ }^{\circ} \mathrm{C}$, in 2 replicates and the average values were taken into account.

\section{Statistical analysis}

Counts of microorganisms were reported as mean values calculated from the results of 3 replicates of mycological analyses of each sample. These were then converted to decimal logarithms, referred to as $\log$ CFU.g ${ }^{-1}$.

The obtained mycological results were evaluated and expressed in isolation frequency (Fr), which is defined as the percentage of samples within which the species or genus occurred at least once. These values were calculated according to González et al. (1996) using the formula (2):

$$
\operatorname{Fr}(\%)=(\mathrm{ns} / \mathrm{N}) \times 100 \quad \text { (2) }
$$

where $n s=$ number of samples within a genus; $\mathrm{N}=$ total number of samples.

\section{RESULTS AND DISCUSSION}

\section{Mycological analyses of honey samples}

In the first part of the study, we analyzed 27 honey samples of Slovak origin. Of these, a total of 21 samples $(78 \%)$ were positive for the presence of yeasts and 14 samples $(52 \%)$ were positive for the filamentous microscopic fungi occurrence. In 6 samples (22\%) no presence of microscopic fungi was found at all. The counts of detected micromycetes are shown in Figure 1. The highest number of yeasts (3.07 log CFU.g $\left.{ }^{-1}\right)$ was recorded in flower honey sample no. 19. According to Snowdon and Cliver (1996), most samples of honey contain detectable levels of yeasts. Although yeast counts in many honey samples are below $100 \mathrm{CFU}^{-1}{ }^{-1}$, yeasts can grow in honey to very high numbers. Bogdanov (2011) states that water content is an important factor for yeast development in the substrate. Honey generally contains osmophilic (sugartolerant) yeasts in greater or lesser amounts. If the moisture content is high enough and storage temperature is favorable, they can ferment substrate (Subramanian, Umesh Hebbar and Rastogi, 2007). Fermentation is an irreversible phenomenon that can run in honey mainly during storage, causing significant economic losses. In such a case, honey presents a characteristic odor, increasing acid flavor and gas bubbles (Perez-Perez, Rodriguez-Malaver and Vit, 2007). Bogdanov (2011) expresses the relationship between fermentation risk and water content as follows. If the water content is $17 \%$ or less - honey is safe regardless of the number of yeasts. If the water content is $17.1-18 \%$ - honey is safe for yeasts up to $1000 \mathrm{CFU}_{\mathrm{g}}{ }^{-1}$ $\left(3 \log \mathrm{CFU} \cdot \mathrm{g}^{-1}\right)$. If the water content is $18.1-19 \%$ - honey is safe for yeasts up to $10 \mathrm{CFU}_{\mathrm{g}} \mathrm{g}^{-1}\left(1 \log \mathrm{CFU} \cdot \mathrm{g}^{-1}\right)$. If the water content is $19.1-20 \%$ - honey is safe for yeasts up to 1 CFU.g ${ }^{-1}\left(<1 \log\right.$ CFU. $\left.g^{-1}\right)$. And finally, if the water content is over $20 \%$ - it is a constant risk of fermentation in honey. Similarly, Subramanian, Umesh Hebbar and Rastogi (2007) mention, that raw honey sample containing more than $20 \%$ moisture readily undergoes fermentation irrespective of the initial yeast count and reduction of moisture content below $17 \%$ is considered to be a safe level for retarding yeast activity. The water content in honey is one of the most important criteria of honey quality. The lower the water content, the more viscous, thick and unchanged honey is since such conditions in honey are unsuitable for the growth of osmophilic yeasts and thus prevent fermentation of honey (Korošec et al., 2016; Čermáková, Chlebo and Husáriková, 2017). A previous study (Kňazovická et al., 2020) on the physico-chemical parameters of honey from 2018 (our first 20 samples) concluded that the water content of the honey did not exceed $20 \%$ and its average value was $17.3 \%$. 


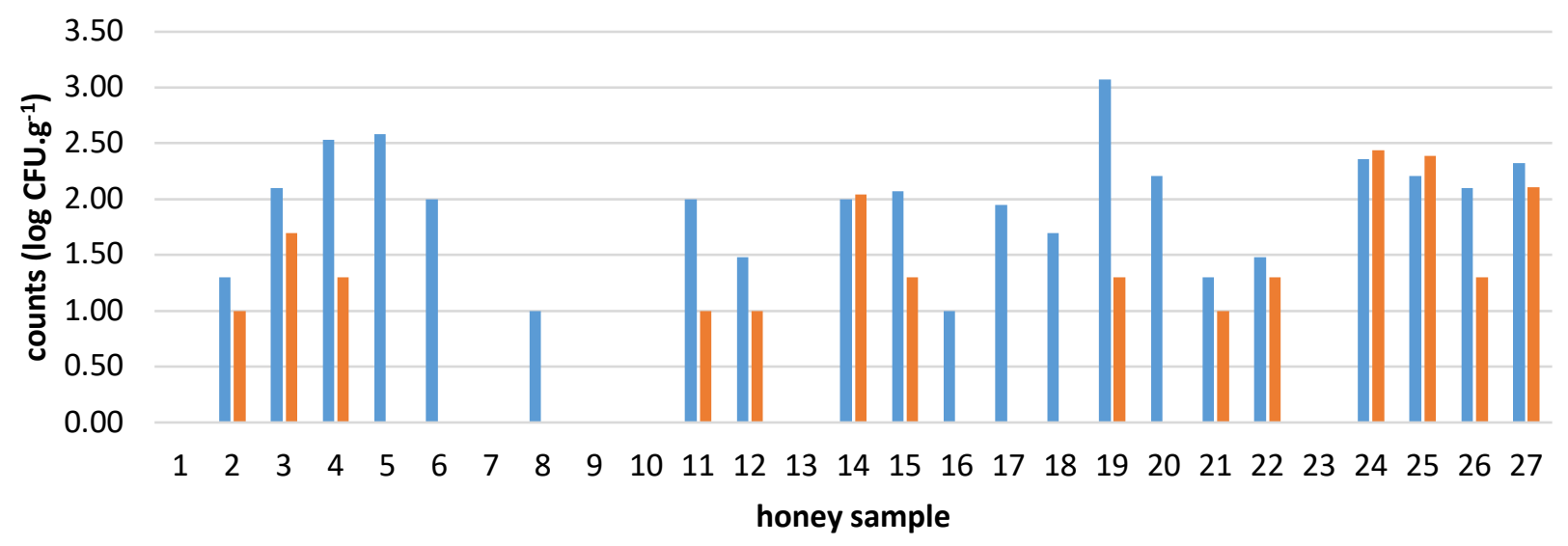

yeasts filamentous microscopic fungi

Figure 1 Counts of detected microorganisms in honey samples of Slovak origin.

From this perspective, except for the flower honey sample no. 19 , we can consider our honey as safe.

In this study, we did not perform yeast genera identification, but the most common yeasts isolated from honey include for example Schizosaccharomyces, Saccharomyces, and Zygosaccharomyces (Silva et al., 2017; Tančinová et al., 2017). Among the isolated Portuguese honey samples, Rhodotorula mucilaginosa, Candida magnoliae, and Zygosaccharomyces mellis were the predominant species. Candida spp. represented more than $45 \%$ of the honey isolates (Carvalho et al., 2010). Authors Sinacori et al. (2014) gave information about the isolation of Debaryomyces hansenii, Zygosaccharomyces rouxii, Zygosaccharomyces mellis, Aureobasidium pullulans, and Cryptococcus uzbekistanensis species from honey. Among them, Cryptococcus species were associated with human pathogenicity. Cryptococcus neoformans is characterized as opportunistic human pathogen, able to infect the central nervous system (Ashbee and Bignell, 2010). Čadež et al., (2014) isolated from bee bread and honey in Hungary five yeast strains representing a hitherto undescribed yeast species. The name Zygosaccharomyces favi sp. nov. is proposed for this new yeast species, which based on phenotype can be distinguished from related Zygosaccharomyces species by its obligate osmophilic nature.

In terms of filamentous micromycetes, the highest numbers we recorded in honeydew honey samples no. 24 and 25 (2.44 a $2.39 \log$ CFU.g ${ }^{-1}$ ). Honeydew kinds of honey are generally reported to contain fungal hyphae and algae when microscopically examined because bees collect honeydew, which is the product of aphids inhabiting green parts of plants. Bees along with honeydew collect additional structures, such as hyphae or spores of fungi, plant pathogens, and algae (Escuredo, Fernández-González and Seijo, 2012). However, we have found that honeydew honey does not necessarily show higher numbers of viable filamentous fungi, because in 4 of the 9 honeydew honey samples we did not detect any occurrence of filamentous fungi. Moreover, no fungi (and hence yeasts) were recorded in one of them.
Considering the genera representation of filamentous fungi, we confirmed the occurrence of the following genera: Alternaria, Arthrinium, Aspergillus (including previously named as Eurotium), Aureobasidium, Cladosporium, Mucor, Penicillium, and Stemphilium. Isolates of the genus Penicillium were recorded with the highest isolation frequency $(41 \%)$. For comparison, research by authors Sinacori et al. (2014), performed with honey samples of different blossoming, pointed out the occurrence of different fungal species - Alternaria alternata, Aspergillus niger, Aspergillus proliferans, Aspergillus spelunceus, Chaetomium globosum, Cladosporium cladosporioides, Daldinia concentrica, Emericella discophora, Emericella qinqixianii, Penicillium corylophilum, Penicillium decumbens, Penicillium polonicum, and Penicillium echinulatum, of which $P$. corylophilum and A. niger were the most frequent, but in the low count, indicating that the honey is capable of containing multiplication of these fungi. Rodríguez-Andrade et al. (2019) have surveyed and evaluated the presence of xerotolerant and xerophilic fungi in a set of honey bee samples collected from across Spain. From 84 samples, a total of 104 fungal strains were isolated. They identified 32 species distributed across 16 genera, most of them belonging to the ascomycetous genera Aspergillus, Bettsia, Candida, Eremascus, Monascus, Oidiodendron, Penicillium, Skoua, Talaromyces, and Zygosaccharomyces. As a result of this survey, eight new taxa were proposed. Other fungi rarely found in their study were Alternaria multiformis, and the mucoralean Cunninghamella bertholletiae, Mucor plumbeus, and Rhizopus oryzae. These probably represent environmental contaminants. Martins, Martins and Bernardo (2003) tested 80 multi-species flower kinds of honey, commercially available in Portugal. They focused on the spores of bacteria and fungi. Yeasts and microscopic filamentous fungi were detected in $88.8 \%$ of the samples, identifying 3 filamentous fungus genera - Aspergillus, Penicillium, and Mucor and 2 yeast genera - Saccharomyces and Candida. Aspergillus spp. fungi are ubiquitous and associated with disease in many insects, plants, animals, and man. They are regarded as opportunistic pathogens that require immunocompromised hosts to establish infection. 
Microbiological studies have shown a high prevalence of Aspergillus spp. in apiaries which occur saprophytically on hive substrates. However, the specific conditions required for pathogenicity to develop remain unknown (Foley et al., 2014). The results of Foley et al. (2014) confirm the ubiquity of Aspergillus spp. in the apiary environment and highlight their potential to infect both larvae and adult bees unknown. Bignell (2010) reported, that food with acidic $\mathrm{pH}$, low humidity, and high concentration of sugars, such as honey, are sources for growth of the fungi Aspergillus glaucus. In our study, Aspergillus species were isolated from $19 \%$ honey samples.

The analysis of filamentous microscopic fungi is now highly emphasized (Kačániová et al., 2006). This is because they can produce mycotoxins that adversely affect human health and reduce the hygienic quality of food. However, the presence of fungi does not imply the presence of mycotoxin; it has necessary ideal conditions such as high water activity, the presence of sugars, and the presence of organic acids capable of reducing $\mathrm{pH}$. Necessary conditions for fungal growth are not always the necessary conditions for the production of mycotoxins (Barkai-Golan and Paster, 2008). Several of the fungi found in honey samples (Aspergillus spp. and Penicillium spp.) are potential producers of mycotoxins, but this does not mean that the honey may represent a risk to the health of the consumer, because (in general) the production of mycotoxins or the fungal growth is suppressed at water activities lower than 0.70 , as is the case of honey ( $\mathrm{a}_{\mathrm{w}}$ of 0.60 or less) (RodríguezAndrade et al., 2019). Despite inappropriate condition found in honey for mycotoxin production, it is important to say that the presence of the fungus can also cause disease in different ways, as induction of allergic responses and infections (An, 2004).

\section{Honey with added fruit}

It is generally known that the raw materials must be of excellent quality to produce a good quality product. If poor quality raw materials with certain defective elements are used, these defects will also pass to the final product. Highquality mature honey is considered to be a food with a minimum number of microorganisms and many beneficial effects in terms of human nutrition compared to other foods and no or negligible health risks. In this part of the study, we focused at first on mycological analysis of the raw materials used for the preparation of honey with the addition of fruit. Secondly, mycological analyses of the final products were carried out. Information concerning the counts of isolated fungi (Figure 2) is supplemented by information on the water activity of the individual samples (Figure 3), which has a significant impact on their occurrence.

Analysis of the basic raw material - rapeseed pasted honey did not show the presence of microscopic fungi. The water activity of this honey sample was 0.567 . Finola, Lasagno and Marioli (2007) reported that the low number of filamentous micromycetes in honey is a good indicator of suitable conditions in the apiary environment.

\section{Honey with blueberries}

Regarding blueberries, only frozen fruits had a water activity value suitable for the growth of microorganisms (0.928). Yeast had the highest values in the lyophilized raw material. This is also associated with the highest yeast value in honey with lyophilized blueberries. According to Dobiás (2004), microorganisms are present in lyophilized products in the inactive state, but when added to honey, they may rehydrate and thus become active. Similarly, the highest number of filamentous fungi we detected in the lyophilized blueberries and the honey with lyophilized blueberries. Filamentous micromycetes were not present in dried blueberries and the product thereof. The water activity of the products ranged from 0.524 to 0.592 - optimal water activity in terms of long-term product stability.

The filamentous fungi most commonly identified in blueberries, were zygomycetes Rhizopus spp. and Mucor spp. The presence of Rhizopus spp. was also observed in honey with lyophilized blueberries. Blueberries can be perishable at high moisture content. After blueberry maturation, physiological changes and tissue softening will occur. The fruits used for the manufacture of the products must not be oppressed or rotten, must be free from infested or otherwise damaged parts (Zambiazi et al., 2016).

This product may have significant nutritional properties. Zambiazi et al. (2016) investigated the antioxidant activity and bioactive substances in blueberries and honey products with the addition of blueberries. Honey with the addition of blueberries achieved excellent results in this experiment regarding the phytochemical content and antioxidant capacity, due to the presence of both raw materials in this product.

\section{Honey with cranberries}

In terms of the highest water activity (0.905) of raw materials, fresh cranberries appear to be the most hazardous. After the addition of fresh cranberries to honey, the water activity of the honey partially increased (0.640). According to Woodbine (1983), osmophilic yeasts could be able to grow in this water activity. However, yeasts were found at relatively low values only in samples of fresh and lyophilized cranberries. They were not even present in honey with lyophilized cranberries, although they were detected in the raw material. The average number of yeasts found in honey with fresh and dried cranberries was in both cases at the limit of detection of $1 \log$ CFU. $g^{-1}$.

The occurrence of filamentous micromycetes in raw materials can be considered as low. According to Woodbine (1983), they can grow in a water activity range of $0.87-0.80$ and the xerophilic filamentous micromycetes have a water activity range of $0.75-0.65$. We detected representatives of Cladosporium and Penicillium genera. Within the products, filamentous fungi were found only in a sample of honey with fresh cranberries, where their number was at the limit of detection. Tadych et al. (2015) mentioned, that cranberry fruit is a rich source of bioactive compounds that may function as constitutive or inducible barriers against rot-inducing fungi. It is well known that it naturally contains benzoic acid, and is commonly added as a preservative to many other fruit and berry products. Higher content of benzoic acid guarantees a good shelf life of fresh and processed fruits (Mateljan, 2017). 


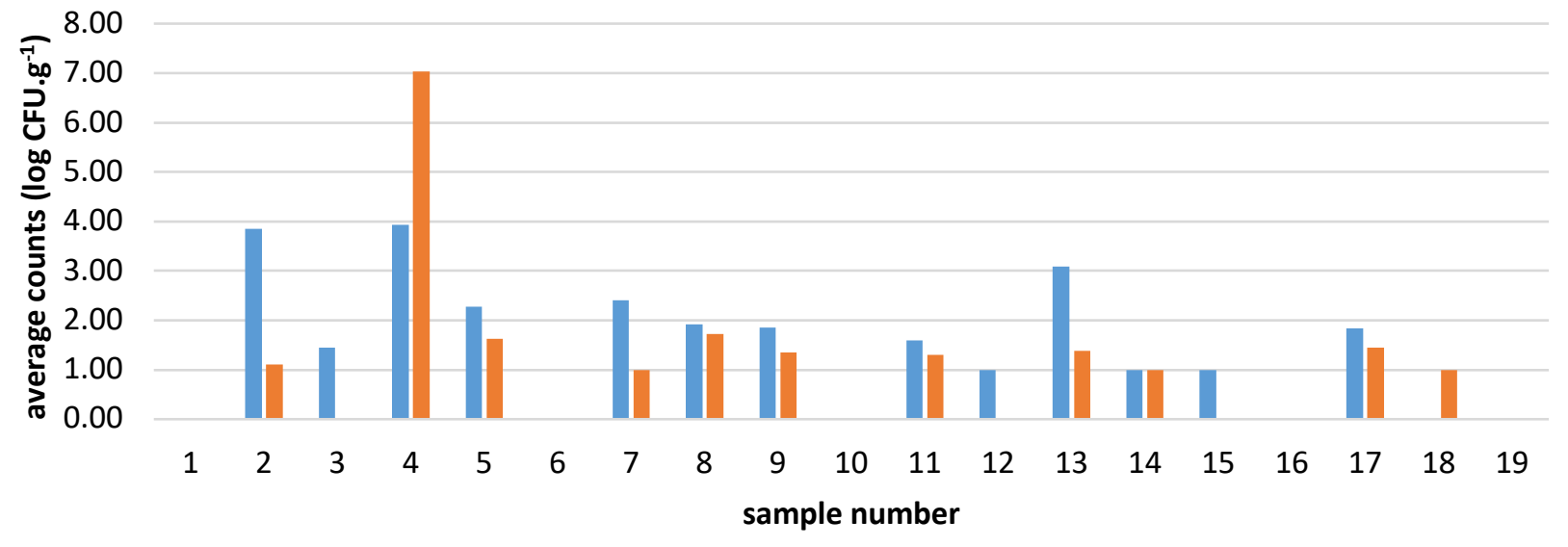

yeasts filamentous microscopic fungi

Figure 2 Mean counts of microorganisms detected in raw materials used for the production of honey with additives and in final products.

Note: $(1$ - honey, 2 - frozen blueberries, 3 -dried blueberries, 4 - lyophilized blueberries, 5 - fresh cranberries, 6 - dried cranberries, 7 - lyophilized cranberries, 8 - frozen red currants, 9 - dried red currants, 10 - lyophilized red currants, 11 honey with frozen blueberries, 12 - honey with dried blueberries, 13 - honey with lyophilized blueberries, 14 - honey with fresh cranberries, 15 - honey with dried cranberries, 16 - honey with lyophilized cranberries, 17 - honey with frozen red currants, 18 - honey with dried red currants, 19 - honey with lyophilized red currants).

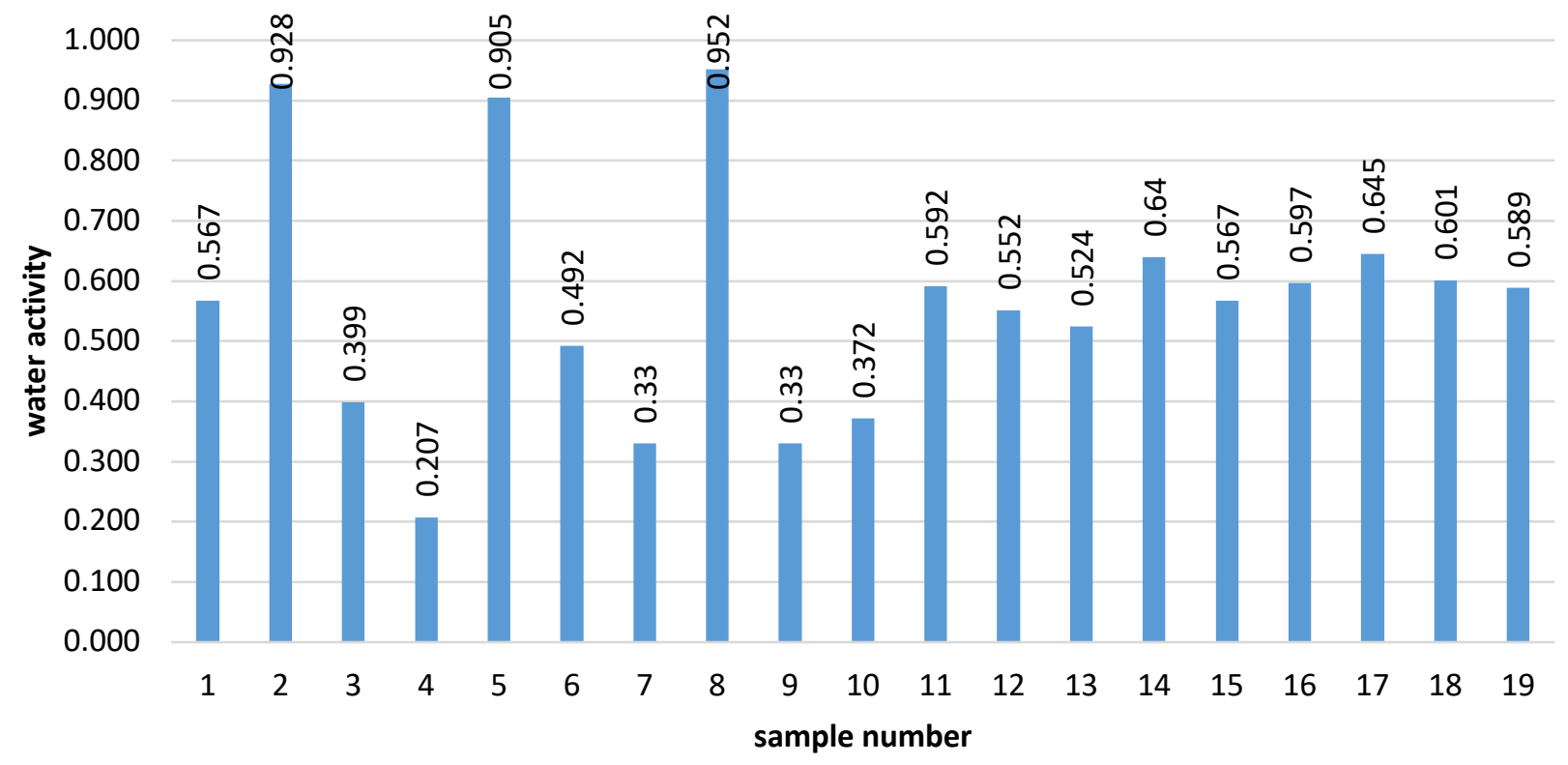

Figure 3 Water activity $\left(a_{w}\right)$ of raw materials used for the production of honey with additives and of final products. Note: (1 - honey, 2 - frozen blueberries, 3 -dried blueberries, 4 - lyophilized blueberries, 5 - fresh cranberries, 6 - dried cranberries, 7 - lyophilized cranberries, 8 - frozen red currants, 9 - dried red currants, 10 - lyophilized red currants, 11 honey with frozen blueberries, 12 - honey with dried blueberries, 13 - honey with lyophilized blueberries, 14 - honey with fresh cranberries, 15 - honey with dried cranberries, 16 - honey with lyophilized cranberries, 17 - honey with frozen red currants, 18 - honey with dried red currants, 19 - honey with lyophilized red currants).

\section{Honey with red currants}

Red currants are a valuable component of a healthy diet because they are an excellent source of ascorbic acid, anthocyanins, and minerals (Nour, Trandafir and Ionica, 2011). The water activity of frozen red currants was the highest (0.952) of all raw materials used in this study.

Woodbine (1983) reports that sporulating bacteria, gramnegative rods, or some yeasts can multiply in such processed fruits. In both dried and lyophilized currants, the water activity values were considerably lower and the growth of microorganisms would not be possible. The highest number of yeasts and filamentous fungi was recorded in frozen currants. Based on this finding, we assume their occurrence in the composite product as well, which was confirmed. Also, this product had the highest water activity (0.645). However, the yeast and filamentous fungi counts were not high (below $2.00 \mathrm{log}$ CFU.g ${ }^{-1}$ ) and some self-regulation is possible over time. The dominant fungi isolated from this raw material were Cladosporium spp. Yeasts or filamentous micromycetes did not occur in 
lyophilized currants or honey with their addition. Yeasts were also not identified in honey with dried fruit.

\section{CONCLUSION}

Honey mycobiota can vary in qualitative and quantitative terms, depending on many factors, such as water activity, or various physico-chemical and biological parameters. For mycological diversity, which can have a significant impact on its quality and safety, it is one of the relatively few investigated commodities. Both yeast and filamentous microscopic fungi can affect honey properties. A total of 27 kinds of honey tested in this study have shown good mycological quality. For yeast occurrence, we can consider our honey samples as safe (except one flower honey sample) because they did not exceed the value $3.00 \mathrm{log}$ CFU. ${ }^{-1}$. The average value in positive samples was 1.94 $\log$ CFU.g ${ }^{-1}$. Similarly, the occurrence of filamentous microscopic fungi in honey samples does not present a significant risk. Their numbers did not exceed $2.50 \mathrm{log}$ CFU. $\mathrm{g}^{-1}$ and the average number in positive samples was $1.51 \log$ CFU.g ${ }^{-1}$. Although we have observed the presence of potential mycotoxin producers, they do not have suitable conditions for production.

In the case of good physico-chemical properties of honey and in particular of sufficiently low water activity, microscopic fungi may survive, but they do not multiply and thus spoil the honey. On the other hand, in the production of various honey products, it is very important to have these properties of products under control, as these microorganisms could reproduce, cause unwanted changes and affect its safety. To produce honey with added fruit we have to use raw materials of excellent (microbiological) quality. Deficiencies in honey, blueberries, cranberries, and red berries can lead to the spoiling of the final product. It is also important to choose the appropriate combination and concentration of raw materials. The study showed that cranberries were the most appropriate addition from a mycological point of view. This may also be related to the reported benzoic acid content. In the case of cranberries and red currants, their lyophilized and dried forms were the most suitable. We have not observed the presence of yeasts or filamentous micromycetes in honey with lyophilized cranberries or currants. In the case of honey with blueberries, the dried fruit variant was the most suitable. Based on the water activity of honey with additions, all products appeared to be stable.

The use of honey in products that receive no or limited heat treatment may require additional tests. More information on the source and control of microorganisms in honey is needed to answer the concerns currently facing the industry. Moreover, it would be advisable in further research to monitor the products in storage studies.

\section{REFERENCES}

An, Z. 2004. Handbook of Industrial Mycology. BOCA RATON, FL, USA : CRC Press, 784 p. eBook ISBN 9780429224560. https://doi.org/10.1201/9780203970553

Aparna, A. R., Rajalakshmi, D. 1999. Honey - its characteristics, sensory aspects, and applications. Food Reviews International, vol. 15, no. 4, p. 455-471. https://doi.org/10.1080/87559129909541199

Ashbee R., Bignell E. M. 2010. Pathogenic Yeasts. HEIDELBERG : Springer-Verlag Heidelberg, 365 p. ISBN
978-3-642-03149-6.

https://doi.org/10.1007/978-3-64203150-2

Barkai-Golan R., Paster N. 2008. Mycotoxins in fruits and vegetables. SAN DIEGO : Academic Press, 408 p. ISBN 78-012-374126-4. https://doi.org/10.1016/B978-0-12-3741264.X0001-0

Bignell, E. 2010. Aspergillus: Molecular Biology and Genomics. By Masayuki Machida and Katsuya Gomi (Eds.). Biotechnology Journal, vol. 5, no. 3, p. 336-337. https://doi.org/10.1002/biot.201000025

Bogdanov, S. 2011. Honey Composition. In The Honey Book Available

https://www.academia.edu/5616849/Composition_of_honey

Carvalho, C. M., Meirinho, S., Estevinho, M. L. F., Choupina, A. 2010. Yeast species associated with honey: different identification methods. Archivos de Zootecnia, vol. 59, no. $225 . \quad$ https://doi.org/10.4321/s000405922010000100011

Chaven, S. 2014. Honey, Confectionery and Bakery Products. In Motarjemi, Y., Lelieveld, H. Food Safety Management: A Practical Guide for the Food Industry. DUBAI, UAE : Academic Press, p. 283-299. ISBN 978-0-12381504-0. $\quad$ https://doi.org/10.1016/b978-0-12-381504$\underline{0.00011-1}$

Čadež, N., Fülöp, L., Dlauchy, D., Péter, G. 2014. Zygosaccharomyces favi sp. nov., an obligate osmophilic yeast species from bee bread and honey. Antonie van Leeuwenhoek, vol. 107 , no. 3, p. 645-654. https://doi.org/10.1007/s10482014-0359-1

Čermáková, T., Chlebo, R., Husáriková, M. 2017. Kniha o mede (Book about the honey). Bratislava, Slovakia : Eastone book. 279 p. ISBN: 978-80-8109-133-9. (In Slovak)

Dadant, G. 2019. How to infuse your own honey. Available at: https://www.dadant.com/learn/how-to-infuse-your-ownhoney/

De Hoog, G. S., Guarro, J., Gene, J. 2000. Atlas of Clinical Fungi. $2^{\text {nd }}$ ed., Utrecht, Netherland : Centralbureau voor Schimmelcultures, 1126 p. ISBN 9789070351434.

Dobiáš J. 2004. Technologie a spracování ovoce a zeleniny I. (Technology and processing of fruit and vegetables I.) Prague, Czech Republic : Vysoká škola chemickotechnologická, 152 p. (In Czech)

Escuredo, O., Fernández-González M., Seijo M. C. 2012. Differentiation of Blossom Honey and Honeydew Honey from Northwest Spain. Agriculture, vol. 2, no. 1, p. 25-37. https://doi.org/10.3390/agriculture2010025

Finola, M. S., Lasagno, M. C., Marioli, J. M. 2007. Microbiological and chemical characterization of honeys from central Argentina. Food Chemistry, vol. 100, no. 4, p. 16491653. https://doi.org/10.1016/j.foodchem.2005.12.046

Foley, K., Fazio, G., Jensen, A. B., Hughes, W. O. H. 2014. The distribution of Aspergillus spp. opportunistic parasites in hives and their pathogenicity to honey bees. Veterinary Microbiology, vol. 169, no. 3-4, p. 203-210. https://doi.org/10.1016/j.vetmic.2013.11.029

González, H. H. L., Pacin, A., Resnik, S. L., Martinez, E. J. 1996. Deoxynivalenol and contaminant mycoflofa in freshly harvested Argentinean wheat in 1993. Mycopathologia, vol. 135, no. 2, p. 129-134. https://doi.org/10.1007/bf00436463

Kačániová M., Kunová S., Haščík, P., Čuboň J. 2006. Microorganisms in honey (Mikroorganizmy v mede). Včelár, vol. 80 , no. 5 , p. 68-69. (In Slovak)

Kňazovická, V., Gábor, M., Miluchová, M., Medo, J., Mašková, Z., Volfová, A., Gažarová, M., Čanigová, M., Ivanišová, E. 2020. Med z hl'adiska fyzikálno-chemických parametrov, prítomnosti rôznych skupín mikroorganizmov a 
jeho využitia - pohl'adom súčasného poznania (Honey in terms of physico-chemical parameters, presence of various groups of microorganisms and its use - from the perspective of current knowledge). E-Newsletter Ústavu včelátstva, vol. 3, no. 1. (In Slovak)

Korošec, M., Kropf, U., Golob, T., Bertoncelj, J. 2016. Functional and Nutritional Properties of Different Types of Slovenian Honey. In Kristbergsson, K., Ötles, S. Functional Properties of Traditional Foods, Boston, USA : Springer, p. 323-338, ISBN 978-1-4899-7660-4. https://doi.org/10.1007/978-1-4899-7662-8 23

Krell, R. 1996. Value-added products from beekeeping. In FAO Agricultural services Bulletin, no. 124, ISBN 92-5103819-8. Available at: http://www.fao.org/3/w0076e/w0076e00.htm

Martins, H. M., Martins M. L., Bernardo F. M. A. 2003. Bacillaceae spores, fungi and aflatoxins determination in honey. Revista Portuguesa de Ciências veterinárias, vol. 98, no. 546, p. 85-88.

Mateljan, G. 2017. The word's healthiest foods. Available at: http://www.whfoods.com/genpage.php?tname=foodspice $\& \mathrm{db}$ $\underline{\mathrm{id}=145}$

Nour, V., Trandafir, I., Ionica, M. E. 2011. Ascorbic acid, anthocyanins, organic acids and mineral content of some black and red currant cultivars. Fruits, vol. 66, no. 5, p. 353-362. https://doi.org/10.1051/fruits/2011049

Olaitan, P. B., Adeleke, O. E., Ola, I. O. 2007. Honey: A reservoir for microorganisms and an inhibitory agent for microbes. African Health Sciences, vol. 7, no. 3, p. 159-165.

Perez-Perez, E., Rodriguez-Malaver, A. J., Vit, P. 2007. Effect of fermentation after harvest on the total antioxidant activity of Tetragonisca angustula honey. Free Radical Res., vol. 41, p. S47-S47.

Pitt J. I. 2000. Toxigenic fungi and mycotoxins. Br. Med. Bull., vol. 56, no. 1, p. 184-192. https://doi.org/10.1258/0007142001902888

Pitt, J. I., Hocking, A. D. 2009. Fungi and Food spoilage. $3^{\text {th }}$ ed. NEW YORK : Springer. 519 p. ISBN 978-0-378-92207-2.

Přídal, A. 2005. Včelí produkty (Bee products). Brno, Czech Republic : MZLU, 61 p. ISBN 80-7157-711-1. (In Czech)

Rao, P. V., Krishnan, K. T., Salleh, N., Gan, S. H. 2016. Biological and therapeutic effects of honey produced by honey bees and stingless bees: a comparative review. Revista Brasileira de Farmacognosia, vol. 26, no. 5, p. 657-664. https://doi.org/10.1016/j.bjp.2016.01.012

Rodríguez-Andrade, E., Stchigel, A. M., Terrab, A., Guarro, J., Cano-Lira, J. F. 2019. Diversity of xerotolerant and xerophilic fungi in honey. IMA Fungus, vol. 10, no. 1. https://doi.org/10.1186/s43008-019-0021-7

Samson, R. A., Hoekstra, E. S., Frisvad, J. C., Filtenborg, O. 2002. Introduction to food- and airborne fungi. UTRECHT : Centraalbureau voor Schimmecultures, p. 283-297. ISBN 9070351-42-0.

Silva, M. S., Rabadzhiev, Y., Eller, M. R., Iliev, I., Ivanova, I., Santana, W. C. 2017. Microorganisms in Honey. In Honey Analysis. https://doi.org/10.5772/67262

Sinacori, M., Francesca, N., Alfonzo, A., Cruciata, M., Sannino, C., Settanni, L., et al.. 2014. Cultivable microorganisms associated with honeys of different geographical and botanical origin. Food Microbiology, vol. 38, p. 284-294. https://doi.org/10.1016/j.fm.2013.07.013

Snowdon, J. A., Cliver, D. O. 1996. Microorganisms in honey. International Journal of Food Microbiology, vol. 31, no. 1-3, p. 1-26. https://doi.org/10.1016/0168-1605(96)00970$\underline{1}$
Soni, A., Oey, I., Silcock, P., Bremer, P. 2016. Bacillus Spores in the Food Industry: A Review on Resistance and Response to Novel Inactivation Technologies. Comprehensive Reviews in Food Science and Food Safety, vol. 15, no. 6, p. 1139-1148. https://doi.org/10.1111/1541-4337.12231

STN ISO 21527-1. 2010. Mikrobiológia potravín a krmív. Horizontálna metóda na stanovenie počtu kvasiniek a plesní. Čast' 1: Metóda počitania kolónii vo výrobkoch s aktivitou vody väčsou ako 0,95 (Microbiology of food and animal feeding stuffs. Horizontal method for the enumeration of yeasts and moulds.Part 1: Colony count technique in products with water activity greater than 0.95) (In Slovak)

STN ISO 21527-2. 2010. Mikrobiológia potravín a krmív. Horizontálna metóda na stanovenie počtu kvasiniek a plesní. Čast' 2: Metóda počitania kolónií vo výrobkoch s aktivitou vody menšou ako 0,95 alebo rovnajúcou sa 0,95 (Microbiology of food and animal feeding stuffs. Horizontal method for the enumeration of yeasts and moulds. Part 2: Colony count technique in products with water activity less than or equal to 0.95) (In Slovak)

Subramanian R., Umesh Hebbar H., Rastogi N. K. 2007. Processing of Honey: A Review. International Journal of Food Properties, vol. 10, no. 1, p. 127-143. https://doi.org/10.1080/10942910600981708

Tadych, M., Vorsa, N., Wang, Y., Bergen, M. S., JohnsonCicalese, J., Polashock, J. J., White, J. F. 2015. Interactions between cranberries and fungi: the proposed function of organic acids in virulence suppression of fruit rot fungi. Frontiers in Microbiology, vol. 6. https://doi.org/10.3389/fmicb.2015.00835

Tančinová, D. - Kačániová, M. - Felšöciová, S. - Mašková, Z. 2017. Mikrobiológia potravín (Food microbiology). $1^{\text {st }}$ ed. NITRA : Slovenská pol'nohospodárska univerzita, 239 p. ISBN 978-80-552-1642-3. (In Slovak)

Umesh Hebbar H., Rastogi N. K., Subramanian, R. 2008. Properties of Dried and Intermediate Moisture Honey Products: A Review. International Journal of Food Properties, vol. 11, no. 4, p. 804-819, https://doi.org/10.1080/10942910701624736

Woodbine, M. 1983. Microbiology of foods. The ecological essentials of assurance and assessment of safety and quality (3rd edn): By D.A.A. Mossel. The University of Utrecht, The Netherlands. 1982. Meat Science, vol. 9, no. 3, p. 235-236. https://doi.org/10.1016/0309-1740(83)90007-4

Zambiazi, R. C., Jansen, C., Bueno-Costa, F. M., Silva, S. S. D., Hartwig, N. 2016. Bioactive compounds and antioxidant activity of blueberry toppings with honey. International food research Journal, vol. 23, no. 6, p. 2375-2383.

\section{Acknowledgments:}

This work was supported by grant KEGA 015SPU-4/2018.

\section{Contact address:}

*Zuzana Mašková, Slovak University of Agriculture in Nitra, Faculty of Biotechnology and Food Sciences, Department of Microbiology, Tr. A. Hlinku 2, 949 76, Nitra, Slovakia, Tel. +4216414432,

E-mail: zuzana.maskova@uniag.sk

ORCID: https://orcid.org/0000-0003-3413-9337

Vladimíra Kňazovická, Institute of Apiculture, Animal Production Research Center, National Agricultural and Food Center, Gašperíkova 599, 033 80, Liptovský Hrádok, Slovakia, Tel.: +421902495599,

E-mail: vladimira.knazovicka@,nppc.sk ORCID: https://orcid.org/0000-0002-3911-9856 
Veronika Mančíková, student of the Slovak University of Agriculture in Nitra, Faculty of Biotechnology and Food Sciences, Tr. A. Hlinku 2, 949 76, Nitra, Slovakia, Tel. +421919434769,

E-mail: xmancikova@is.uniag.sk

ORCID: https://orcid.org/0000-0002-3335-6164

Dana Tančinová, Slovak University of Agriculture in Nitra, Faculty of Biotechnology and Food Sciences, Department of Microbiology, Tr. A. Hlinku 2, 949 76, Nitra, Slovakia, Tel. +4216414433,

E-mail: dana.tancinova@uniag.sk

ORCID: https://orcid.org/0000-0001-6790-8169
Zuzana Barboráková, Slovak University of Agriculture in Nitra, Faculty of Biotechnology and Food Sciences, Department of Microbiology, Tr. A. Hlinku 2, 949 76, Nitra, Slovakia, Tel. +4216414494,

E-mail: zuzana.barborakova@uniag.sk

ORCID: https://orcid.org/0000-0001-9890-3993

Corresponding author: * 